Original Research Paper

\title{
The Effect of Cherry Leaves Extract (Muntingia calabura) on Growth Performance of White Shrimp (Litopenaeus vannamei)
}

\author{
Shurathil Uyun ${ }^{1 *}$, Ayu Adhita Damayanti ${ }^{1}$, Fariq Azhar ${ }^{1}$ \\ ${ }^{1}$ Program Studi Budidaya Perairan, Fakultas Pertanian, Universitas Mataram, Indonesia
}

\author{
Article History \\ Received : January $27^{\text {th }}, 2021$ \\ Revised : February $23^{\text {th }}, 2021$ \\ Accepted : March 01 ${ }^{\text {th }}, 2021$ \\ Published : March 11 $1^{\text {th }}, 2021$ \\ *Corresponding Author: \\ Shurathil Uyun, \\ Program Studi Budidaya \\ Perairan, Fakultas Pertanian, \\ Universitas Mataram, Mataram, \\ Indonesia \\ Email: \\ shurathiluyun@yahoo.com
}

\begin{abstract}
Cherry leaf is a natural ingredient that can be used as a feed additive because it contains flavonoids, tannins, saponins, triterpene and polyphenols which are antioxidants. This study aims to determine the effect of giving cherry leaf extract on the growth of vaname shrimp. A total of 20 vannamei shrimp in the PL-20 phase measuring $\pm 0.1 \mathrm{~g} /$ head are kept in a 40 liter container. The method used in this study was an experimental method using a completely randomized design (CRD) with 4 treatments and 3 replications, namely P1: feeding without cherry leaf extract (control), P2: feeding with the addition of $1 \%$ cherry leaf extract, P3: feeding with the addition of $2 \%$ cherry leaf extract and P4: feeding with the addition of 3\% cherry leaf extract. The data obtained were analyzed by ANNOVA test with a confidence level of $95 \%$ and Duncan's continued test. The results of this study indicate that the addition of cherry leaf extract can affect the growth of vaname shrimp, but has no effect on the FCR value and survival rate. The addition of cherry leaf extract to a concentration of 3\% can increase the growth of absolute weight and length and the specific growth rate of vaname shrimp which is better than the treatment without the addition of cherry leaf extract. Therefore cherry leaf extract has the potential to be used as a feed additive.
\end{abstract}

Keywords: Cherry Leaf Extract, Growth, Vaname Shrimp

\section{Pendahuluan}

Udang vaname (Litopenaeus vannamei) merupakan salah satu komoditas budidaya perikanan yang unggul di Indonesia. Udang vaname memiliki nilai jual yang cukup tinggi. Nilai ekspor udang vaname berdasarkan data KKP mengalami kenaikan sekitar $10,40 \%$ pada tahun 2012-2017. Keunggulan lain udang vaname menurut Utami et al. (2016) yaitu memiliki laju pertumbuhan yang lebih cepat, lebih tahan terhadap penyakit dan toleransi terhadap lingkungan yang tinggi.

Salah satu kendala yang sering dihadapi yaitu terkait hama dan penyakit. Adanya serangan penyakit pada udang dapat mempengaruhi tingkat pertumbuhan udang vaname. Udang yang terkena penyakit akan mengalami penurunan sistem imun sehingga nafsu makan menurun dan pertambahan bobot dan panjang udang terhambat. Upaya yang dapat dilakukan yaitu dengan pemberian feed additive.
Feed additive adalah penambahan suatu bahan dalam pakan yang dapat mempengaruhi kesehatan dan produktivitas biota yang dipelihara (Candinegara, 2020). Penggunaan feed additive untuk mempertahankan daya tahan tubuh udang vaname dapat dilakukan dengan penambahan bahan alami sehingga menggurangi efek negatif terhadap lingkungan.

Daun kersen (Muntingia calabura) adalah salah satu tumbuhan yang mudah didapatkan dan ketersediaanya melimpah. Daun kersen ini merupakan bahan alami yang dapat digunakan sebagai feed addictive. Menurut Puspitasari \& Wulandari (2017), daun kersen mengandung flavonoid, tanin, saponin, triterpenoid dan polifenol yang merupakan antioksidan. Antioksidan pada daun kersen dapat berfungsi untuk mengurangi kerusakan oksidatif akibat radikal bebas dalam tubuh sehingga kesehatan udang terjaga dan udang dapat tumbuh dengan baik. Rosidah et al. (2018) menyatakan bahwa penggunaan ekstrak daun kersen efektif untuk 
pengobatan benih ikan nila yang terinfeksi Aeromonas hydrophila. Menurut Anggawati et al. (2019), penggunaan senyawa flavonoid dapat meningkatkan pertumbuhan udang vaname dengan menjaga kondisi tubuh udang dari patogen yang menyerang pencernaan udang. Pada penelitian Junaidi et al. (2020) penambahan $2 \%$ ekstrak daun mangrove Rhizophora apiculata yang mengandung flavonoid, tanin, saponin, alkanoid dan terpenoid juga dapat meningkatkan performa pertumbuhan udang vaname. Oleh karena itu penelitian ini dilakukan untuk mengetahui pengaruh ekstrak daun kersen terhadap pertumbuhan udang vaname.

\section{Bahan dan Metode}

\section{Pelaksanaan Penelitian}

Penelitian ini dilaksanakan selama 60 hari pada bulan September - November 2020 di Laboratorium Budidaya Perairan, Program Studi Budidaya Perairan dan Laboratorium Kimia, Universitas Mataram. Penelitian ini menggunakan metode Rancangan Acak Lengkap (RAL) dengan 4 perlakuan dan 3 ulangan sehingga diperoleh 12 unit percobaan. Adapun perlakuan penelitian ini yaitu $\mathrm{P} 1=$ pemberian pakan tanpa penambahan ekstrak daun kersen, P2 $=$ pemberian pakan dengan penambahan ekstrak daun kersen $1 \%, \mathrm{P} 3=$ pemberian pakan dengan penambahan ekstrak daun kersen $2 \%$ dan $\mathrm{P} 4=$ pemberian pakan dengan penambahan ekstrak daun kersen $3 \%$.

\section{Prosedur penelitian}

Daun kersen yang telah dipilih, lalu diangin-anginkan selama 1 jam dan dimasukkan dalam oven pada suhu $60^{\circ} \mathrm{C}$ selama 24 jam. Selanjutnya daun lalu ditimbang sebanyak $150 \mathrm{~g}$ dan dimasukkan ke dalam tabung erlenmeyer. Serbuk daun kersen selanjutnya dicampur pelarut etanol $96 \%$ dengan perbandingan 1:4. Kemudian dimaserasi selama $3 \times 24$ jam dan diaduk setiap 6 jam. Filtrat yang dihasilkan kemudian di saring dan dipekatkan dengan rotary evaporation selama 3 jam pada suhu $40^{\circ} \mathrm{C}$. Selanjutnya didapatkan ekstrak daun kersen yang diinginkan (Sulaiman et al., 2017).

Pakan yang akan digunakan selama pemeliharaan udang yaitu pelet komersial yang memiliki kandungan protein sebanyak $34 \%$.
Pakan yang sudah disediakan nantinya terlebih dahulu akan diberikan larutan ekstrak daun kersen dan diaduk hingga homogen kemudian diberikan pada udang yang dipelihara. Udang vaname yang akan digunakan yaitu benur udang vaname yang berada pada fase PL-20 yang berukuran $\pm 0,1 \mathrm{~g} / \mathrm{ekor}$. Wadah yang digunakan pada penelitian ini yaitu bak kontainer yang berukuran 40 liter yang diisi air sebanyak 20 liter. Setiap wadah pemeliharaan akan diisi sebanyak 20 ekor udang. Wadah yang digunakan akan dilengkapi dengan shelter, perangkat aerasi dan sistem pergantian air setiap satu kali sehari secara berkala (Fadillah et al., 2019).

Pemeliharaan udang diawali dengan aklimatisasi selama seminggu sebelum diberikan perlakuan. Pergantian air dilakukan setiap hari sebanyak $10 \%$ dari volume total akuarium. Setiap 10 hari dilakukan penimbangan berat untuk menghitung pertambahan berat dan jumlah pakan yang diberikan. Dosis pakan yang akan diberikan yaitu sebanyak 5\% dari berat biomass tiap akuarium. Pakan diberikan sebanyak 4 kali sehari yaitu pada pukul $07.00 ; 11.00 ; 17.00$ dan 22.00 .

\section{Parameter penelitian}

Parameter penelitian yang diamati yaitu pertumbuhan bobot mutlak, $\mathrm{W}=\mathrm{Wt}-\mathrm{Wo}$ (Effendie, 1979 dalam Pratama et al., 2017); pertumbuhan panjang mutlak, $\mathrm{L}=\mathrm{L}_{\mathrm{t}}-\mathrm{L}_{0}$ (Effendie, 1979 dalam Nadhif, 2016); laju pertumbuhan spesifik, SGR = $\frac{\text { LnWt-LnWo }}{\mathrm{t}} \times 100 \%$ (Zonneveld et al., 1991 dalam Ihsanudin et al., 2014); rasio konversi pakan, FCR $=\frac{\mathrm{F}}{\mathrm{Bf}-\mathrm{Bi}}$ (Sammouth et al., 2009 dalam Utami et al., 2018); tingkat kelangsungan hidup, SR $=\frac{\mathrm{Nt}}{\mathrm{No}} \times 100 \%$ (Effendie, 1979 dalam Pratama et al., 2017), uji proksimat dan parameter kualitas air.

\section{Analisis data}

Data hasil penelitian dianalisis dengan menggunakan One Way Annova dengan SPSS pada taraf signifikan 5\% untuk mengetahui pengaruh dari perlakuan dalam penelitian. Jika hasilnya menunjukkan adanya pengaruh nyata, maka dilakukan analisis lanjut dengan uji Duncan. 


\section{Hasil dan Pembahasan}

\section{Pertumbuhan bobot mutlak}

Nilai pertumbuhan bobot mutlak udang vaname yang diamati selama masa pemeliharaan dapat dilihat sebagai berikut (Gambar 1).

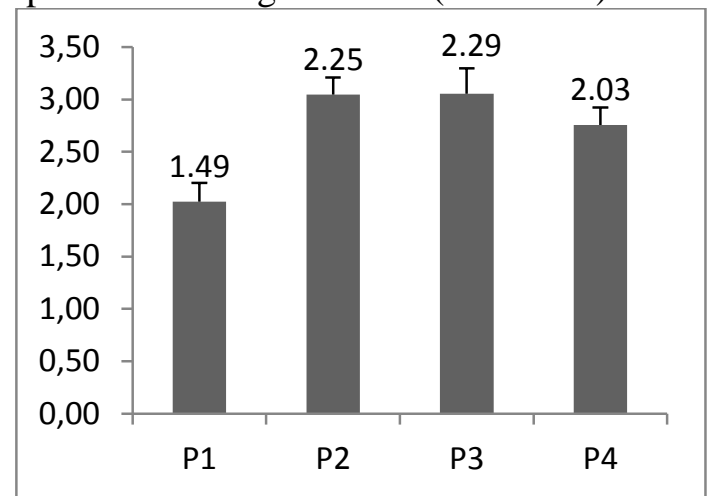

Gambar 1. Pertumbuhan bobot mutlak udang vaname

Pertumbuhan bobot mutlak tertinggi yang diperloeh selama 60 hari masa pemeliharaan yaitu terdapat pada perlakuan P3 (Pakan + ekstrak daun kersen 2\%) dengan nilai 2,29 gr, kemudian diikuti oleh P2 (Pakan + ekstrak daun kersen 1\%) sebesar 2,25 gr, selanjutnya P4 (Pakan + ekstrak daun kersen 3\%) dengan nilai 2,03 gr dan yang terendah terdapat pada P1 (Pakan tanpa pemberian ekstrak) yaitu 1,49 gr. Namun secara statistik dengan uji One-Way Annova dan uji lanjut Duncan, diperoleh pengaruh signifikan $(\mathrm{P}>0,05)$ antara $\mathrm{P} 1$ dengan perlakuan lainnya. Perlakuan $\mathrm{P} 1$ berbeda nyata dengan semua perlakuan lainnya.

Pertumbuhan bobot mutlak yang diberikan ekstrak daun kersen lebih tinggi dibandingkan pertumbuhan bobot mutlak udang vaname tanpa penambahan ekstrak dan kersen. Hal ini diduga karena pengaruh dari penambahan ekstrak daun kersen dapat membantu penyerapan nutrisi pakan, terutama protein yang lebih baik. Menurut Widjaya et al. (2019), bahwa senyawa metabolit sekunder yang terdapat pada ekstrak etanol daun kersen yaitu flavonoid, tanin, saponin dan terpenoid. Kandungan flavonoid pada daun kersen dapat berperan sebagai antibakteri dan antioksidan yang dapat meminimalkan patogen pada saluran pencernaan sehingga diduga dapat meningkatkan daya cerna pada udang vaname. Menurut Anggawati et al. (2019), pertumbuhan udang vaname dapat meningkat karena senyawa flavonoid dapat menjaga kondisi tubuh udang dari patogen yang menyerang pencernaan udang.
Berdasarkan jumlah dosis ekstrak daun kersen yang berbeda terlihat bahwa semakin tinggi dosis ekstrak daun kersen yang diberikan. maka akan semakin meningkat pertumbuhan bobot udang vaname. Akan tetapi, pertumbuhan udang mengalami penurunan pada pemberian ekstrak dengan dosis 3\%. Hal ini diduga karena dosis ekstrak yang terlalu tinggi sehingga dapat menggangu penyerapan komponen nutiren pada pakan. Menurut Andayani et al. (2017), pemberian dosis yang terlalu tinggi tidak dapat menstimulasi imun karena tubuh ikan tidak mampu merespon mekanisme respon seluler dan humoral, antibodi tidak terbentuk dan mungkin akan dihasilkan efek racun.

\section{Pertumbuhan panjang mutlak}

Nilai pertumbuhan panjang mutlak udang vaname yang diamati selama masa pemeliharaan dapat dilihat sebagai berikut (Gambar 2).

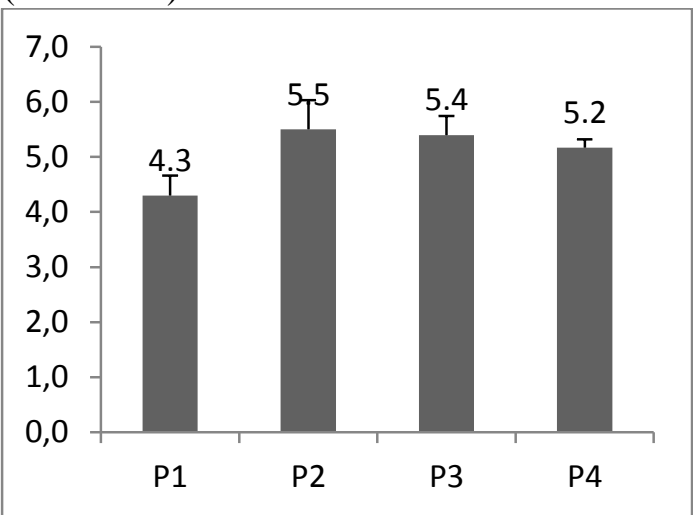

Gambar 2. Pertumbuhan panjang mutlak udang vaname

Pertumbuhan panjang mutlak udang vaname tertinggi terdapat pada perlakuan P2 (Pakan + ekstrak daun kersen 1\%) sebesar 5,5 $\mathrm{cm}$, diikuti oleh P3 (Pakan + ekstrak daun kersen $2 \%$ ) yaitu 5,4 cm, P4 (Pakan + ekstrak daun kersen $3 \%$ ) sebesar $5,2 \mathrm{~cm}$ dan yang terendah pada perlakuan P1 (Pakan tanpa pemberian ekstrak) yaitu 4,3 cm. Namun demikian secara statistik dengan uji One-Way Annova dan uji lanjut Duncan, diperoleh pengaruh signifikan $(\mathrm{P}>0,05)$ antara $\mathrm{P} 1$ dengan perlakuan lainnya. Perlakuan P1 berbeda nyata dengan semua perlakuan lainnya.

Berdasarkan hasil uji One Way Annova diketahui bahwa penambahan ekstrak daun kersen memberikan pengaruh terhadap 
pertumbuhan panjang mutlak udang vaname. Perbedaan pertumbuhan pada udang yang diberikan ekstrak daun kersen dengan pertumbuhan pada udang tanpa ekstrak daun kersen diduga dikarenakan adanya flavonoid yang terdapat pada daun kersen. Kandungan senyawa flavonoid pada ekstrak daun memiliki sifat antioksidan yang dapat menjaga kesehatan udang sehingga udang dapat tumbuh dengan baik. Menurut Hatami et al. (2020), senyawa flavonoid memiliki fungsi sebagai antioksidan yang mampu memperbaiki sel-sel yang rusak akibat radikal bebas. Flavonoidyang merupakan antibakteri yang dapat meminimalkan patogen pada saluran pencernaan sehingga penyerapan nutrien optimal. Menurut Sholikhatin et al. (2014), terdapat 3 mekanisme flavonoid sebagai antibakteri yaitu, menghambat sintesis asam nukleat, menghambat fungsi membran sitoplasma dan menghambat metabolisme energi.

Pada perlakuan pemberian ekstrak daun kersen dengan dosis $3 \%$, pertumbuhan udang cenderung lebih rendah daripada pada perlakuan dengan dosis $1 \%$ dan $2 \%$. Hal ini diduga karena dosis ekstrak yang digunakan terlalu tinggi sehingga tidak mampu meningkatkan pertumbuhan dan sebaliknya menghambat pertumbuhan udang vaname. Adanya kandungan tanin yang terlalu tinggi tidak baik untuk udang. Menurut Rolin et al. (2015), tanin dapat mengikat enzim pencernaan atau komponen penting seperti protein dan mineral. Semakin tinggi dosis ekstrak daun kersen yang diberikan, maka akan semakin tinggi pula kandungan zat tersebut.

\section{Laju pertumbuhan spesifik (SGR)}

Nilai laju pertumbuhan spesifik udang vaname yang diperoleh selama masa pemeliharaan dapat dilihat sebagai berikut (Gambar 3).

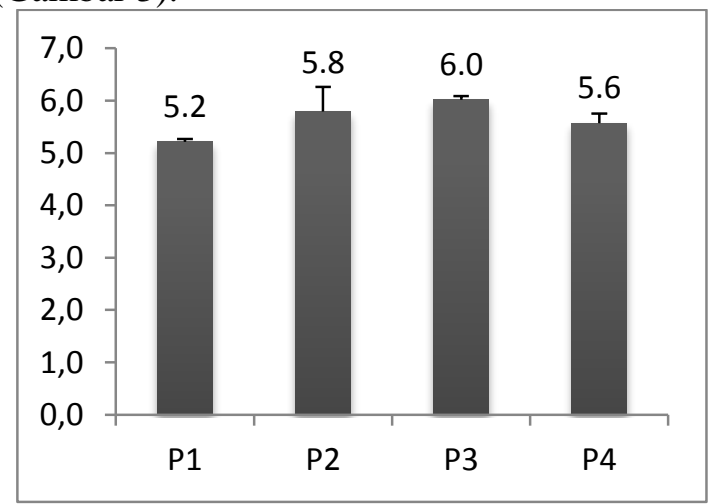

Gambar 3. Laju pertumbuhan spesifik udang vaname

Laju pertumbuhan spesifik udang vaname yang tertinggi terdapat pada perlakuan P3 (Pakan + ekstrak daun kersen $2 \%$ ) sebesar 6\%, diikuti oleh P2 (Pakan + ekstrak daun kersen 1\%) sebesar 5,8\%. Sementara laju pertumbuhan spesifik P4 (Pakan + ekstrak daun kersen 3\%) sebesar 5,6\% dan yang terendah pada P1 (Pakan tanpa pemberian ekstrak) yaitu $5,1 \%$. Namun secara statistik dengan uji One-Way Annova dan uji lanjut Duncan menunjukkan hasil yang berpengaruh signifikan $(\mathrm{P}>0,05)$ antara $\mathrm{P} 1$ dengan P3. Perlakuan P2 dan P4 tidak signifikan dengan P1 dan P3.

Berdasarkan Gambar 3 diketahui bahwa laju pertumbuhan spesifik udang yang diberikan ekstrak daun kersen lebih tinggi daripada laju pertumbuhan spesifik udang tanpa pemberian ekstrak daun kersen. Hal ini menunjukkan bahwa pemberin ekstrak daun kersen mampu meningkatkan laju pertumbuhan spesifik udang vaname. Adanya kandungan flavonoid menunjukkan aktivitas antioksidatif dan antimikroba pada daun kersen menjaga kesehatan tubuh udang sehingga dapat tubuh dengan baik. Senyawa flavonoid ini berfungsi sebagai antimikrobia, antivirus dan antioksidan (Zahara \& Suryady, 2018). Menurut Junaidi et al. (2020), meningkatnya performa pertumbuhan udang vaname ini ditimbulkan dengan peningkatan faktor kesehatan udang melalui kegiatan sistem imun yang diperkuat dengan pemberian imunostimulan. Keberadaan bakteri patogen menyebabkan pertumbuhan udang terhambat. Saat udang terserang penyakit, sebagian besar energi akan digunakan untuk pertahan tubuh sehingga energi untuk pertumbuhan berkurang. Oleh karena itu, udang yang sehat mampu untuk tubuh dengan baik karena dapat memanfaatkan pakan dengan optimal.

Udang yang sehat dapat memanfaatkan pakan dengan baik sehingga pertumbuhan udang meningkat. Sehingga penambahan ekstrak daun kersen yang mengandung flavonoid, saponin, tanin dan terpenoid mampu meningkatkan pertumbuhan udang vaname. Pada penelitian Junaidi et al. (2020) penambahan 2\% daun mangrove Rhizophora apiculata yang mengandung flavonoid, tanin, saponin, alkanoid dan terpenoid juga dapat meningkatkan performa 
pertumbuhan udang vaname. Selain itu, pada penelitian yang dilakukan oleh Hatami et al. (2020), pemberian ekstrak daun sirih merah yang mengandung flavonoid pada pakan udang dengan dosis $0,5 \%$ mampu meningkatkan performa pertumbuhan udang vaname.

Perlakuan P4 pemberian ekstrak daun kersen dengan dosis 3\% memiliki nilai laju pertumbuhan yang lebih rendah daripada P2 dan P3. Hal ini dikarenakan kadar abu yang tinggi seperti yang terlihat pada tabel 1 mempengaruhi pertumbuhan udang vaname. Menurut Gunawan \& Khalil (2015), kadar abu mempengaruhi daya cerna dan pertumbuhan ikan.

\section{Rasio konversi pakan (FCR)}

Nilai konversi pakan yang diperoleh dari pemeliharaan udang vaname selama 60 hari dapat dilihat sebagai berikut (Gambar 4).



Gambar 4. Rasio konversi pakan

Nilai konversi pakan udang vaname tertinggi pada perlakuan P1 (Pakan tanpa pemberian ekstrak) sebesar 1,3, diikuti oleh P2 (Pakan + ekstrak daun kersen 1\%), P3 (Pakan + ekstrak daun kersen 2\%) dan P4 (Pakan + ekstrak daun kersen 3\%) masing-masing sebesar 1,2. Namun demikian berdasarkan hasil analisis data One-Way Annova pada taraf kepercayaan 95\% menunjukkan pemberian ekstrak daun kersen tidak memberikan pengaruh signifikan $(\mathrm{p}>0,05)$ terhadap nilai konversi pakan udang vaname.

Nilai konversi pakan merupakan gambaran keefektivitasan suatu pakan. Nilai konversi pakan pada semua perlakuan tidak berbeda nyata. Diduga disebabkan karena kandungan nutrisi pakan pada semua perlakuan masih layak untuk udang vaname seperti yang ditampilkan pada Tabel 1. Nilai konversi pakan yang diperoleh pada semua perlakuan tergolong baik karena memiliki nilai yang rendah. Rasio konversi pakan yang semakin kecil menandakan semakin cocok makanan tersebut untuk menunjang pertumbuhan ikan yang dipelihara (Saopiadi et al., 2012). Menurut Hatami et al. (2020), efisiensi pakan yang diberikan ditunjukkan dengan rendahnya nilai konversi pakan karena hampir semua pakan dimanfaatkan oleh udang.

\section{Kelangsungan hidup}

Tingkat kelangsungan hidup atau survival rate udang vaname yang dipelihara selama 60 hari dapat dilihat sebagai beriku (Gambar 5).

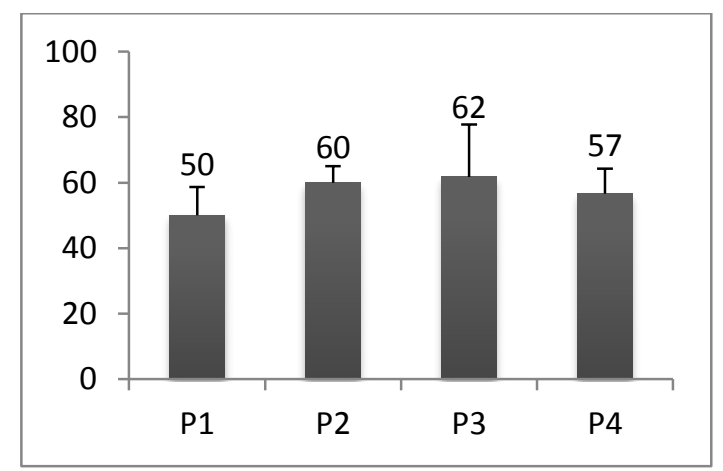

Gambar 5. Tingkat kelangsungan hidup udang vaname

Tingkat kelangsungan hidup udang vaname tertinggi diperoleh pada perlakuan udang vaname yang tertinggi terdapat pada perlakuan P3 (Pakan + ekstrak daun kersen 2\%) sebesar $62 \%$, kemudian diikuti oleh P2 (Pakan + ekstrak daun kersen $1 \%$ ) yaitu 57\%. Sedangkan P4 (Pakan + ekstrak daun kersen 3\%) sebesar 53\% dan yang terendah P1 (Pakan tanpa pemberian ekstrak) yaitu 50\%. Namun demikian hasil analisis statistik One-Way Annova menunjukkan bahwa pemberian ekstrak daun kersen tidak memberikan pengaruh yang signifikan $(p>0,05)$ terhadap tingkat kelangsungan hidup udang vaname.

Hasil penelitian menunjukkan bahwa pemberian ekstrak daun kersen pada pakan tidak memberikan pengaruh yang signifikan terhadap tingkat kelangsungan hidup udang vaname. Tingkat kelangsungan hidup yang tidak berbeda nyata ini diduga disebabkan karena kualitas air pemeliharaan pada semua perlakuan masih berada pada kisaran yang layak untuk budidaya udang vaname. Menurut Pratama et al. (2017), faktor abiotik yang mempengaruhi tingkat kelangsungan hidup udang vaname yaitu kualitas air. Kualitas air yang baik akan menyebabkan proses fisiologi dalam tubuh udang berjalan 
dengan baik sehingga mendukung pertumbuhan dan tingkat kelangsungan hidup udang vaname.

Rata-rata tingkat kelangsungan hidup udang vaname pada semua perlakuan yang cukup rendah yaitu berkisar antara 50\% - 62\%. Hal ini diduga disebabkan karena tingginya kepadatan udang dalam wadah sehingga tingkat kelngsungan hidup udang cukup rendah. Menurut Yuniarso (2006) terdapat 2 faktor yang mempengaruhi kelangsungan hidup antara lain kepadatan, kompetitor, penyakit, umur dan kemampuan adaptasi. Tingginya padat tebar udang vaname menyebabkan tingginya kanibalisme akibat berkurangnya ruang gerak udang dalam wadah pemeliharaan. Hal ini sejalan dengan pendapat Fendjalang et al. (2016) yang menyatakan bahwa tingkat kelangsungan hidup yang rendah dapat dikarenakan padat tebar yang tinggi sehingga terjadi kompetisi dalam pemanfaatan ruang dan pakan.

\section{Analisis proksimat}

Data hasil uji proksimat pakan yang ditambahkan ekstrak daun kersen dan tanpa penambahan ekstrak daun kersen dapat dilihat sebagai berikut (Tabel 1).

Tabel 1. Hasil uji proksimat

\begin{tabular}{cccccc}
\hline Perlakuan & Air (\%) & Abu (\%) & Lemak Kasar (\%) & Serat Kasar (\%) & Protein Kasar (\%) \\
\hline P1 & 8,2 & 8,6 & 8 & 0,6 & 34 \\
P2 & 10,5 & 16,7 & 8,3 & 2,3 & 35,4 \\
P3 & 10,7 & 16,8 & 8,6 & 3,5 & 35,8 \\
P4 & 10,8 & 17 & 8,7 & 3,7 & 36,2 \\
\hline
\end{tabular}

Berdasarkan Tabel 2 dapat diketahui bahwa kadar air, kadar abu, kadar lemak, kadar serat kasar dan kadar protein tertinggi dijumpai pada P4. Nilai protein tertinggi pada P4 sebesar $36,2 \%$, dan terendah pada P1 yaitu $34 \%$. Sementara kadar serat kasar tertinggi pada P4 sebesar 3,7\% dan terendah terdapat pada P1 yaitu $0,6 \%$. Kadar lemak kasar tertinggi terdapat pada perlakuan P4 sebesar 8,7\%, sedangkan yang terendah pada P1 yaitu $8 \%$. Kadar abu tertinggi pada $\mathrm{P} 4$ sebesar $17 \%$ dan terendah pada P1 yaitu 8,6\%. Kadar air tertinggi pada P4 sebesar 10,8\% dan terendah pada perlakuan P1 yaitu $8,2 \%$.

Berdasarkan hasil analisa proksimat pakan pada Tabel 1. diketahui bahwa kadar protein pakan berkisar antara 34\%-36,2\%. Kisaran kadar protein pakan pada penelitian ini sudh cukup untuk memenuhi kebutuhan protein udang vaname. Menurut Lee \& Lee (2018) kebutuhan protein udang vaname yaitu sebesar 33\%-44\%. Kadar serat kasar pada pakan yang digunakan berkisar 0,6\%-3.7\%. Kadar serat kasar pada semua perlakuan ini juga masih layak untuk pakan udang menurut SNI (2013) yaitu <6\%. Lemak kasar pada pakan juga masih pada kisaran yang baik yaitu berkisar antara 8\%-8,7\%. Kadar lemak kasar berdasarkan SNI (2013) mutu pakan udang vaname yang baik yaitu $<6 \%$. Sedangkan kadar abu pada pakan yang didapatkan tergolong tinggi yaitu $8,6 \%-17 \%$. Kadar abu yang baik untuk pakan udang vaname berdasarkan SNI (2013) yaitu sebesar <12\%. Namun demikian, kadar abu yang cukup tinggi pada pakan masih dapat meningkatkan pertumbuhan udang vaname. Kadar air pada pakan di semua perlakuan berkisar antara 8,2\%-10,8\%. Kisaran kadar air pada pakan yang digunakan pada penelitian masih tergolong layak untuk pakan sesuai dengan standar pakan udang vaname SNI (2013) yaitu maksimal $12 \%$.

\section{Kualitas air}

Data hasil pengukuran kualitas air selama masa pemeliharaan udang vaname dapat dilhat sebagai berikut (Tabel 2).

Tabel 2. Parameter kualitas air

\begin{tabular}{ccc}
\hline $\begin{array}{c}\text { Kualitas } \\
\text { Air }\end{array}$ & Nilai & Nilai Standar \\
\hline \multirow{2}{*}{ Suhu } & $27.7-$ & $25-31^{\circ} \mathrm{C}$ \\
& 28.7 & $\begin{array}{c}\text { Kurniawan dan Heru, } \\
\text { 2019) }\end{array}$ \\
DO & $6.4-7.8$ & $>4(\mathrm{WWF}, 2014)$ \\
pH & $7.9-8.3$ & $7,5-8,5(\mathrm{WWF}, 2014)$ \\
Salinitas & $28-33$ & $28-33(\mathrm{WWF}, 2014)$ \\
\hline
\end{tabular}


Berdasarkan Tabel 2 diketahui bahwa nilai parameter kualitas air selama kegiatan budidaya masih tergolong baik untuk pertumbuhan udang vaname. Nilai suhu selama penelitian pada semua perlakuan berkisar antara $27,7-28,7^{\circ} \mathrm{C}$. Kisaran nilai suhu ini sudah sesuai untuk kehidupan dan pertumbuhan udang vaname. Menurut Kurniawan dan Heru (2019), nilai suhu yang ideal untuk udang antara $25-31^{\circ} \mathrm{C}$. Nilai oksigen terlarut pada semua perlakuan berkisar antara $6,4-7,8 \mathrm{ppm}$. Nilai oksigen terlarut ini tergolong baik untuk pertumbuhan dan kehidupan udang sesuai standar oksigen terlarut menurut WWF (2014) yaitu > 4 ppm. Sedangkan hasil pengukuran nilai $\mathrm{pH}$ selama penelitian yaitu berkisar 7,9 - 8,3. Kondisi $\mathrm{pH}$ selama penelitian masih tergolong normal untuk hidup udang. Menurut WWF (2014) kisaran pH ideal yang mendukung kelangsungan hidup dan pertumbuhan udang yaitu $7,5-8,5$. Hasil pengukuran salinitas selama pemeliharaan udang vaname sudah baik untuk kehidupan dan pertumbuan udang vaname dengan kisaran 30-32 ppt. Menurut WWF (2014), salinitas 28 - 33 ppt merupakan salinitas yang ideal untuk pertumbuhan udang vaname.

\section{Kesimpulan}

Hasil penelitian ini menunjukkan bahwa penambahan ekstrak daun kersen dapat mempengaruhi pertumbuhan udang vaname (Litopenaeus vannamei), namun tidak berpengaruh terhadap nilai FCR, dan tingkat kelangsungan hidupnya. Penambahan ekstrak daun kersen sampai dengan konsentrasi 3\% dapat meningkatkan pertumbuhan berat dan panjang mutlak serta laju pertumbuhan spesifik udang vaname yang lebih baik jika dibandingkan perlakuan tanpa penambahan ekstrak daun kersen. Oleh karena itu ekstrak daun kersen mempunyai potensi untuk dimanfaatkan sebagai feed additive.

\section{Ucapan terima kasih}

Penulis mengucapkan terimakasih kepada semua pihak yang sudah membantu dalam proses dan penyelesaian penelitian ini. Ucapan terima kasih kepada bapak Fariq Azhar yang telah memberikan berbagai bantuan dalam pelaksanaan penelitian, ibu Ayu Adhita
Damayanti dan ibu Salnida Yuniarti Lumbessy atas saran dan bimbingannya.

\section{Referensi}

Andayani, S., Fajar, M. \& Rahman, M. F. (2017). Effect of Alkaloids Derived from Jelyfish on the Intestinal Histopathology and Relative Percentage Survival (RPS) of Tiger Grouper (Epinephelus fuscoguttatus) Infected by Vibrio harveyi. IOP-Publishing. 22-42. DOI: https://iopscience.iop.org/article/10.1088/ 1755-1315/137/1/012006

Anggawati, Hilyana, S. \& Marzuki, M. (2019). Pengaruh Penambahan Ekstrak Kulit Manggis (Garcinia mangostana) dengan Konsentrasi Berbeda terhadap Pertumbuhan dan Kelangsungan Hidup Udang Vaname (Litopenaeus vannamei). Jurnal Perikanan. 9(2). 172-179. DOI: http:/www.jperairan.unram.ac.id/index.ph $\mathrm{p} / \mathrm{JP} /$ article/view/164

Badan Standarisasi Nasional. (2013). SNI 7813:2013. Pakan Buatan untuk Produksi Benih Udang Vaname (Litopenaeus vannamei). BSN, Jakarta.

Candinegara, T. (2020). Challenges of Using Feed Additives in Indonesia. IOPPublishing. DOI: https:/www.researchgate.net/publication/ 342433496_Challenges_of_using_feed_a dditive_in_Indonesia

Fadillah, N., Waspodo, S. \& Azhar, F. (2019). Penambahan Ekstrak Daun Mangrove Rhizophora apiculata pada Pakan Udang Vaname (Litopenaeus vannamei) untuk Pencegahan Vibriosis. Journal of Aquaculture Science. 4 (2). 91-101. DOI: https://www.researchgate.net/publication/ 336129926_Penambahan_Ekstrak_Daun_ mangrove Rhizophora apiculata pada-

Pakan_Udang_Vaname_Litopenaeus_van namei untuk Pencegahan Vibriosis

Fendjalang, S. N. M., Budiardi, T., Supriyono, E. \& Effendi, I. (2016). Produksi Udang Vaname pada Karamba Jaring Apung 
dengan Padat Tebar Berbeda di Selat Kepulauan Riau. Jurnal Ilmu dan Teknologi Kelautan Tropis. 8(1). 201-214. DOI:

https://ejournal.unkhair.ac.id/index.php/k sppk/article/view/648

Gunawan \& Khalil, M. (2015). Analisis Proksimat Formulasi Pakan Pelet dengan Penambahan Bahan Baku Hewani yang Berbeda. Acta Aquatica. 2(1). 23-30.

Hatami, A., Waspodo, S. \& Azhar, F. (2020). Pengaruh Pemberian Ekstrak Daun Srih Merah (Piper crocatum) terhadap Performa pertumbuhan Udang Vaname. Jurnal Ruaya. 8(2). 122-127. DOI: https://www.researchgate.net/publication/ 343315528 PENGARUH PEMBERIAN EKSTRAK_DAUN_SIRIH_MERAH_P iper crocatum TERHADAP PERFORM A PERTUMBUHAN UDANG VANA ME Litopenaeus vannamei

Ihsanudin, I., Rejeki, S. \& Yuniarti, T. (2014). Pengaruh Pemberian Rekombinan Hormon Pertumbuhan (rGH) melalui Metode Oral dengan Interval Waktu yang Berbeda terhadap Pertumbuhan dan Kelulushidupan Benih Ikan Nila Larasati. Journal of Aquaculture Management and Technology. 3(2). 94-102.

Junaidi, M., Azhar, F., Setyono, B. D. H. \& Waspodo, S. (2020). Pengaruh Pemberian Ekstrak Daun Mangrove Rizhophora Apiculata terhadap Performa Pertumbuhan Udang Vaname. Buletin Veteriner Udayana. 12(2). 198-204.

Kurniawan, A. \& Heru N. (2019). Sistem Monitoring $\mathrm{pH}$ dan Suhu Air pada Tambak Udang Menggunakan Protokol Websocket. Jurnal Pengembangan Teknologi Informasi dan Ilmu Komputer. 3(4), 3174-3181.

Lee, C. dan Lee, K. J. (2018). Dietary Protein requirement of Pasific White Shrimp Litopenaeus vannamei in Three Different Growth Stage. Fisheries and Aquatic Sciences. 21(30). 1-6.
Nadhif, M. (2016). Pengaruh Pemberian Probiotik pada Pakan dalam Berbagai Konsentrasi terhadap Pertumbuhan dan Mortalitas Udang Vaname (Litopenaeus vannamei. Skripsi sebagai salah satu syarat kelulusan di Program Studi Biologi, Departemen Biologi, Fakultas Sains dan Teknologi, Universitas Airlangga, Surabaya

Pratama, A., Wardiyanto \& Supono (2017). Studi Performa Udang Vaname (Litopenaeus vannamei) yang Dipelihara dengan Sistem Semi Intensif pada Kondisi Air Tambak dengan Kelimpahan Plankton yang Berbeda pada Saat Penebaran. Jurnal Perekayasaan dan Teknologi Budidaya Perairan. 6(1).

Puspitasari, A. D. \& Wulandari R, L. (2017). Aktivitas Antioksidan dan Penetapan Kadar Flavonoid Total Ekstrak Etil Asetat Daun Kersen (Muntingia calabura). Jurnal Pharmascience. 4(2). 167-175.

Rolin, F., Setiawan, M. \& Jusadi, D. (2015). Evaluasi Pemberian Ekstrka Daun Kayu Manis Cinnamomu burmanii pada Pakan terhadap Kinerja Pertumbuhan Ikan Patin Pangasianodon hypophthalmus Sauvage. Jurnal Ikhtiologi Indonesia. 15(3). 201208.

Rosidah, Lili, W., Iskandar \& Afpriliansyah, M. R. (2018). Efektivitas Ekstrak Daun Kersen untuk Pengobatan Benih Ikan Nila yang Terinfeksi Bakteri Aeromonas hydrophila. Jurnal Akuatika Indonesia. 3(1). 10-18.

Saopiadi, Amir, S. \& Damayanti, A. A. (2012). Frekuensi Pemberian Pakan Optimum Menjelang Panen pada Ikan Nila (Orechromis niloticus). Jurnal Perikanan Unram. 1(1). 14-21. DOI: http://jperairan.unram.ac.id/index.php/JP/ article/view/9

Solkhatin, E., Sarwiyono \& Surjowardojo, P. (2014). Ekstrak Etanol Daun Kersen (Muntingia calabura) sebagai Antimikroba terhadap Bakteri 
Streptococcus agalactiae pada Sapi Perah di Daerah Ngantang. Skripsi sebagai salah satu syarat kelulusan di Fakultas Peternakan Universitas Brawijaya, Malang.

Sulaiman, A. Y., Astuti, P., \& Shita, A. D. P. (2017). Uji Antibakteri Ekstrak Daun Kersen (Muntingia calabura L). terhadap Koloni Strepcoccus viridans. 1(2).

Utami, K. P., Hastuti, S. \& Nugroho, R. A. (2018). Pengaruh Kepadatan yang Berbeda terhadap Efisiensi Pemanfaatan Pakan, Pertumbuhan dan Kelulushidupan Ikan Tawes (Puntius javanicus) pada Sistem Resirkulasi. Jurnal Sains Akuakultur tropis. 2(2). 53-63.

Utami, W., Sarjito \& Desrina. (2016). Pengaruh Salinitas terhadap Efek Infeksi Vibrio harveyi pada Udang Vaname (Litopenaeus vannamei). Journal of Aquaculture Management and Technology. 5(1). 82-90.

Widjaya, S. R., Bodhi, W. \& Yudistira, A. (2019). Skrining Fitokimia, Uji Aktivitas Antioksidan, dan Toksisitas Ekstrak Daun Kersen dengan Metode 1.1-diphenyl-2picrylhydrazyl (DPPH) dan Brine Shrimp Lethality (BSLT). Pharmacon. 8(2). 335343.

WWF. (2014). Seri Panduan Perikanan Skala Kecil, BMP Budidaya Udang Windu (Penaeus monodon) Tambak Tradisional dan Semi Intensif. WWF Indonesia: Indonesia.

Yuniarso, T. (2006). Peningkatan Kelangsungan Hidup, Pertumbuhan, dan Daya Tahan Udang Windu (Penaeues monodon fab.) Stadium PL 7-PL 20 Setelah Pemberian Silase Artemia yang Telah Diperkaya dengan Silase Ikan. Skripsi sebagai salah satu syarat kelulusan di Jurusan Biologi, Fakultas Mtematika dan Ilmu Pengetahuan Alam, Universitas Sebelas Maret, Surakarta.

Zahara, M. \& Suryady. (2018). Kajian Morfologi dan Review Fitokimia Tumbuhan Kersen
(Muntingia calabura L). Jurnal Ilmiah

Pendidikan dan Pembelajaran. 5(2). 